\title{
The Voice of the Voiceless: Reflections on Science Practical Work in Rural Disadvantaged Schools
}

\author{
Dr Abraham Motlhabane \\ University of South Africa \\ mot/hat@unisa.ac.za
}

Doi:10.5901/mjss.2013.v4n14p165

\section{Abstract}

This article articulates the unsatisfactory conditions for doing practical work in science subjects in secondary schools. It explores how teachers teach science without having the necessary equipment to do such work. I shall attempt to show that practical work has many benefits to the teaching and learning of science and every learner should be afforded an opportunity to do it. Often teachers try to explain a practical experiments theoretically to learners. This is done in the hopes that learners will understand the science concepts, even though the teacher and the learners have to "imagine" as if science concepts were reality. My argument is that, during the examination period, all learners are assessed on the same level irrespective of whether the practical activity was done on not. Many learners do practical work for the first time at tertiary level, without having had the proper training and background for doing practical work. Consequently, the results in Physical Science continue to be below par, as evidenced in the Grade 12 results. This study is a reflection on the experiences of teachers and that of the author at 30 schools in the rural areas of South Africa.

Keywords: disadvantaged schools, laboratory work, physical science, practical activities, practical work, rural schools, secondary schools, theoretical practical

\section{Introduction}

Practical work is under siege in both wealthy developed countries and poor developing countries (Bradley, Durbach, Bell and Mungarulire 1998:1406). While literature indicates that there are a number of positive outcomes from practical work in the teaching of science at secondary schools, its usefulness continues to come under scrutiny. Some researchers still question its suitability. To put it bluntly, not all researchers truly believe in the worth of practical work. Moreover, the usefulness and effectiveness of practical work in teaching science at secondary schools is doubted by many researchers. These researchers, according to Cilliers, Basson, Kirschner and Rutherford (2000), do not believe practical work is effective in helping learners learn science. In addition, Abrahams (2009) argues that practical work generates short-term engagement and is relatively ineffective in generating motivation to study science in the longer term. Learners' attitudes towards secondary school science can become progressively more negative over time. Although many researchers have documented the positive effect practical work has on learners towards science, it remains the responsibility of those involved in science education to develop a more realistic understanding of the limitations of practical work in the affective domain. Nonetheless, the role of practical work has been praised in developed countries (Treagust \& Thair 1999; Tamir 1991; Hofstein \& Cohen 1996; Van der Linder, Van der Wal \& Wilkinson 1994). In countries with a tradition of practical work in school science, such as the United Kingdom, it is often seen by teachers and others, particularly scientists, as central to the appeal of science (Abrahams 2009). Thus, international comparisons (such as TIMSS) show that learners in the UK spend more time on practical activities than do learners in most other countries. The evidence seems to suggest that the amount of practical work in schools in the UK has not varied substantially in recent years (TIMMS 2011).

Even though the economy of South Africa cannot be compared with that of the UK, the South African science curricula should endeavour to include significant amounts of practical activities. In addition, the necessary resources should be provided. This is because learners learn by doing and thinking about what they do (Lowery 1994). As a result, the focus should be directed at facilitating active learning among learners (Coleman, Holcomb \& Rigden 1997).

Some researchers, according to Cilliers et al (2000), still regard practical work as the teaching of practical skills. However, this is an issue that requires a separate discussion. With much interest directed at productive reinforcement of the outcomes of practical work, some enthusiastic researchers, such as Bradley et al (1998), have posed serious questions about the cost-effectiveness and purpose of practical work. On the subject of the cost effectiveness, there has 
been global efforts to reduce costs involved in the manufacturing and distribution of science equipments. The initiatives has been welcomed by many teachers, especially teachers who previously did not have equipments. However, for some schools these equipments were not used. Reasons given by teachers include the fact that they were not trained to use the equipments. For some schools, teachers claim the equipments are very small and cannot be used for schools with large class sizes. This imply that, large classes will have to divide into smaller groups. Consequently, the equipments will be defective after only one practical session. In an attempt to use the equipments for longer periods, some teachers demonstrate the a science practical to group of learners. This means that learners will observe what the teacher is doing and if the group is too big, learners will not be able to see what is happening because of the size of the equipments. Learners will not be able manipulate equipments and participate in the actual doing part. By implication, science practical work should generally incorporate three components. Firstly, learners must "hear" what is happening. Secondly, they must "do" the actual science practical. Lastly, they must "see" what is happening. In the absence of these components, the practical activity is incomplete. Consequently, teachers theorise a practical activity.

In the current economic status, it may look like a wise move to reduce the sizes of equipments, thereby reducing the costs to accommodate schools (disadvantaged schools) that cannot afford the conventional equipments. However the move has a negative effect in the long run, because the quality is compromised. At the same time the purpose of practical work as evidenced in the literature shows that what learners can achieve when they engage in practical work and what the teachers' intentions are with practical work may unintentionally lead to ambiguous conclusions. Accordingly, it could easily lead to both positive and negative indicators of the learners' acquisition of knowledge, skills and attitudes. In this reflective piece I shall focus on the plight of the rural disadvantaged schools in their attempts to do practical work in science. For the purpose of this study the term "rural disadvantaged schools" refers to schools that do not have the necessary science equipment to do practical work.

\section{What is Practical Work?}

Several studies have pointed out various definitions of practical work. To some, practical work might mean laboratory work or experiments performed as teacher demonstrations. Others believe that practical work involves hands-on experimentation by learners in a laboratory or classroom. In most cases the phrase "laboratory work" is used interchangeably with the phrase "practical work". Laboratory work is used in the context that experiments are done in the laboratory, while practical work may refer to experiments done anywhere, for instance outside the classroom, in the classroom or in the laboratory. Indeed, the typical laboratory (Yager 1991:22) may not be a laboratory at all. The term "laboratory" can be used to describe a place where learners can test their own ideas and/or their own explanations for the objects and events they have encountered as they explore the universe in which they find themselves. In addition, the term can be used to describe a place where science learners engage in hands-on activities such as observations and experiments; in other words, not only to verify but also to find or discover. While the laboratory may be used to illustrate objects, concepts, processes and experiments, its uniqueness lies in providing learners with opportunities to engage in the processes of investigation and enquiry (Tamir 1977:311).

The scope of practical work could be extended to include activities such as project work, library research, fieldwork, site visits, environmental monitoring and investigating technologies (Bradley \& Maake 1998). For this reason, practical work may be performed in any number of locations and need not be limited to the classroom or laboratory. Any learning method that requires the learner to be active, rather than passive, is in accordance with the belief that learners learn best by direct experiences, which is what practical work in fact is (Hodson 1992:67). Legitimate alternatives can include computer-assisted learning (CAL), use of worksheet activities in conjunction with the teacher, a demonstration or video or film presentation, working with case study materials, interviewing, debating and role-playing, writing tasks, making models, posters and scrapbooks, library work of various kinds and making videos.

In physical science classes practical work may mean hands-on as well as minds-on practical work activities such as laboratory experiments. With hands-on and minds-on activities learners do experiments on their own, while the teacher acts as a facilitator. With distance education, learners can engage in distance practical work, in which case learners can observe practical work via video or television without hands-on participation. In the case of demonstrations, learners can observe a practical being demonstrated by the teacher in the classroom. Learners may participate by observing, asking and answering questions. In group or individual practical work learners perform practical work in the classroom. Learners can also participate by making, doing, measuring, observing, asking and answering questions (Bradley \& Maake 1998:4). In general, practical work can include all types of investigation or experimentation by learners on their own or in groups, as well as demonstrations by teachers (Van der Linde et al 1994:49). 
While there may be a wide variety of definitions of practical work, Bekalo and Welford (2000:187) assert that practical work should always involve learner participation, although people may differ in their understanding of the degree of this participation (Bradley \& Maake 1998:4).

\section{Why Practical Work?}

Generally, school science curriculum in most countries has two distinct purposes. First, it aims to provide every young person with sufficient understanding of science to participate confidently and effectively in the modern world - a 'scientific literacy' aim. Second, advanced societies require a steady supply of new recruits to jobs requiring more detailed scientific knowledge and expertise. Hence, school science provides the foundations for more advanced study leading to such jobs (Millar 2004). These two purposes may lead to different criteria for selection of curriculum content, to different emphases, and (in the particular context of this paper) to different rationales for the use of practical work. According to Millar (2004), improving learners' scientific knowledge and their knowledge of science as a form of enquiry - has led many science teachers to argue that science education should combine and integrate them into a 'seamless' whole. The idea is that learners should be taught to carry out their own scientific enquiries and so acquire scientific knowledge for themselves. Subsequent to Millar's 2004 argument, learners must play an active role in 'taking on' the new knowledge. He or she has to 'make sense' of the experiences and the discourse of the science class, and use it to 'construct meaning'. Similarly, the content of science involves the material world, hence it seems natural, and rather obvious to emphasise that learning science should involve seeing, handling and manipulating real objects and materials, and that teaching science should involve acts of 'showing' as well as of 'telling'.

Practical work in school science was previously seen as a means of obtaining factual information or data. Many other researchers - such as Haslam and Hamilton (2010), Abrahams (2010), Gyllenpalm, Wickman and Holmgren (2010) - unanimously agree that practical work in schools can assist in the exploration, manipulation and development of concepts and can also make the concepts manifest, comprehensible and useful. However, Lunetta, Hofstein and Clough (2007) argues that the quality of practical work varies considerably and there is a strong evidence, from many countries that when the practical activity is well planned and effectively implemented, it can stimulate experiences of learner's learning in varying levels of inquiry. This can help learners to be mentally and physically engaged in ways that are not possible in other science education experiences. Evidence of effective practice in the use of practical work comes from a range of studies. For example, White and Gunstone's (1992) study indicates that learners must manipulate ideas as well as materials in the school laboratory. Furthermore, there is a growing body of research (Abrahams 2010, Lunetta et al 2007, Haslam \& Hamilton 2010) that shows the effectiveness of 'hands-on' and 'minds-on' activities in school science inside and outside the laboratory.

While the call for scientific literacy, as a general goal for science education, has emphasised the need for learners to develop an understanding beyond scientific concepts and skills, at least according to Gyllenpalm et al 2010, researchers such as Hofstein and Cohen (1996), Millar (1991), and Haslam and Hamilton (2010) agree that practical experiences are essential for the development of skills and strategies. These could have wide-ranging effects in terms of generalisation to other areas of the learner's development.

Additional skills can be learnt during science practicals. For example, learners can learn organisational skills, learn to work independently and cooperatively within a group and also be aware of the time requirements of different tasks; in other words, time management skills (Bentley \& Watts 1989).

Science education can provide learners with real experience of the whole scientific process. This process includes identifying a problem, proposing possible explanations and devising tests to determine the validity of a particular situation. A successful experience in practical-related activities may engender feelings of self-esteem, self-confidence and determination that could be transferable to a wider world outside the laboratory. The development of positive attitudes towards science and the scientific enterprise (Woolnough 1991) is among the major aims of science teaching. As Koballa and Crawley (1985), Bradley and Maake (1998), Bentley and Watts (1989), and Tamir (1991) explain, practical work can be an effective environment for enhancing learners' attitudes towards and interest in the learning of science. Although the curriculum specifies that practical and investigative activities must be carried out by learners. It has to be noted that there is a gap between policy and practice, between what is written in curriculum documents, what teachers say they do, and what learners actually experience. For example, Lunetta, et al (2007) noted that despite a recent shift of emphasis towards learning outcomes, the evidence suggests that there is a 'chasm' between what teachers identify as their outcomes before lessons and the outcomes that their learners perceive. 


\section{Theoretical Framework}

For this study the reflective judgement model (RJM) was used because there is continued controversy and doubt about the success of practical work in bringing about effective teaching and learning. Reflection on the experience of the teachers and that of the author in 30 secondary schools is seen as potentially transformative to everyone involved in the teaching and learning of science. In the context of this study reflective practice was viewed as specific to the application of experiential learning related to practical activities carried out as part of teaching and learning. This experiential learning, with its emphasis on the improvement of practice through reflection on experience, involves the learner-teacher going through a sequence of actions indistinguishable from those of the action research spiral (King \& Kitchener 2004). Following on Kolb's widely influential model of the experiential learning cycle, reflection on science practical work in rural schools was followed by generalisation and abstract conceptualisation (McMahon 2006).

Figure 1: Kolb's experiential learning framework

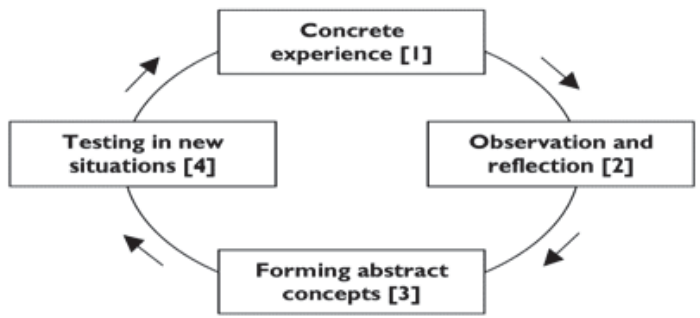

Source: Knowles, Holton and Swanson (2005:198)

The major similarity between Kolb's learning cycle and the action research spiral is that they both emphasise the importance of reflection on action and experience. This reflection involves observation, discovery, and collaborative inquiry and discourse through shared experience. Life experience is seen as both a resource and a stimulus for learning. In both models the reflection is intended to be transformative. In the case of the learning cycle, this transformation can be mainly internal (i.e. concerned with knowledge or attitude) according to McMahon (2006). Greater emphasis is put on the externally observable results of transformation in terms of improvements to the way practical work is done. However, in terms of the reflective practitioner model of teaching and learning, the strategic dimension is not only the most valid distinguishing feature, but also the key to an understanding of how the two can be usefully related in practice. Reflective practice was thus used to identify problems and challenges.

In addition, practical work was observed as it took place in the natural setting. Therefore the study recorded behaviour as it happens. As a participant-observer I played an active role in the experience that was being studied (Nicholls 2009b:641; Merriam 1998:94/96). The physical setting in the classrooms and laboratories, participants (the teachers and learners as they do practical work), practical activities and interactions, conversations, as well as informal and unplanned activities were observed (Merriam 1998:97). Field notes, as an additional method of recording observations, was also used.

\section{Situation Analysis}

Many schools have been struggling to do practical work before and since 1994. As reported by Van der Linde et al (1994), $38 \%$ of teachers taught in laboratories, whilst $62 \%$ used classrooms for the teaching of physical science. At least $25 \%$ of the laboratories did not have water and electricity or gas supplies, whilst less than $50 \%$ of the educators had mechanical and electrical apparatus at their disposal. The situation regarding facilities and apparatus available in ordinary classrooms used as laboratories for practical work was indicated as even more unsatisfactory.

Regardless of the wide acceptance in developed countries of practical activities in school science, the literature shows that questions have been raised regarding the effectiveness of the practical-related activities (Bradley et al 1998:1406) and lack of evidence supporting the supposed benefits. Some researchers have suggested that much of what takes place in school laboratories is of little value, ill-conceived and unproductive (Treagust \& Thair 1999:358). 
Developing countries often use practical activities as a means of confirming theory. This can be seen as a game by learners where intelligent learners discover the right answers. The main feature of most classroom transactions in rural schools revolve around the transfer of factual information through "chalk-and-talk" and confirmation of taught concepts through routine-guided experimental approaches. In many schools, the teachers themselves often do not have the necessary expertise to organise, carry out and evaluate practical-oriented courses (Bekalo \& Welford 2000:203). This may, in part, be due to the difficulties in accessing information, a lack of access to libraries, computer information networks and journals, and limited textbooks. Many of the education systems in developing countries are inherited from the former colonial powers, and in some cases continue to be influenced by outside curriculum experts. In many cases these education systems have adopted the latest educational trends from developed countries, where the strategies are based on the premise that learners do more practical work (Treagust \& Thair 1999:358).

Many commentators on practical work agree that the effectiveness of practical activities in developing countries is inconclusive and suggest that as long as science achievement tests neglect to measure the skills developed during practical activities, scepticism will remain concerning their measurable benefits (Treagust \& Thair 1999:358). Authors (Hodson 1992:65; Van der Linde et al 1994:48; Bradley et al 1998:1406) have commented on the inconclusiveness and lack of research on the effects of practical work in developing countries. They suggest caution in drawing conclusions about the value of practical activities in developed countries and applying these to developing countries. There are differences (Treagust \& Thair 1999:358) in context between the two types of culture (developed and developing countries). The purpose of schooling and its outcomes provide an example for many learners in developing countries where their first contact with electricity and factory-produced technical artefacts may occur in a school science laboratory. Therefore, practical activities may serve a different purpose for these learners to those in a developed country.

The South African curriculum prescribes the use of practical activities. However, a number of constraints may prevent the implementation of these activities in the classroom. Commonly reported constraints include a lack of equipment (Waterman \& Thompson 1989:31), large classes (Bradley \& Maake 1998:21), overcrowded syllabi, and an examination system focused on factual recall, while ignoring formal assessment of practical outcomes and the application of scientific reasoning to solve problems (White 1988:107; Treagust \& Thair 1999:358; Bekalo \& Welford 2000:207). The situation is even worse in rural areas.

Considering the difficulties in implementing meaningful practical activities, the uncertain outcomes and high costs, I would like to agree with some authors who suggest that practical activities can probably only be recommended for learners in high-income countries and should be limited to those learners destined for post-secondary science studies (Treagust \& Thair 1999:358). For the sake of poor communities (rural schools) the solution to the cost problem lies in the reduction of scale (Jeschofnig 2001; Bradley et al 1998:1407). A reduction in the quantities of chemicals reduces the cost of consumables, equipment costs, and hazard and waste disposal problems. Such a reduction in scale could eliminate the need for specialised and sophisticated laboratories in many cases, and reduce the requirement for storage space. It is suggested that small-scale practical work could provide an economic solution to such problems. Although the existence of classroom laboratories and equipment may not be used as a criterion for measuring the quality of teaching (Van der Linde et al 1994:5), it may be an essential facility for schools if the teachers were to use a practical teaching approach.

The challenge in trying to do practical work in schools is that over the past three decades, research has shown that learners come to science classes with pre-instructional conceptions and ideas about the phenomena and concepts to be learnt that are not in harmony with scientific views. These conceptions and ideas are firmly held and are often resistant to change (Treagust \& Duit 2008). Furthermore, the most important single factor influencing learning is what the learner already knows (Ausubel 1968). On top of that, science teachers are overwhelmed by challenges such as learners' lack of interest in science, teachers' inadequate knowledge of science, schools' lack of resources, and society's lack of interest in education - they do not need to be further weighed down by illusory challenges, if indeed this is what the constructivist challenge amounts to. A theoretical consideration is the very justification of science in the curriculum.

\section{Practical Work in Rural Schools}

All schools are required to do practical work. However, different schools do practical work for different purposes. For some, it is to confirm theory. This notion is contested by Bradley and Maake (1998), who argue that practical work should be done with the purpose of developing a positive attitude among learners. This positive attitude (Kobala \& Crawley 1985:227) is important in fulfilling basic psychological needs such as the need to know and succeed. This means that rural schools should let learners participate in activities that can influence their attitudes towards science. These include 
hands-on activities which may only be possible for schools that have enough equipment/apparatus or fewer learners. However, in those schools with limited equipment the teachers do demonstrations. In most cases, in a demonstration, the teacher is doing the experiment and learners are observing. Demonstrations can be a powerful method for bringing about a positive change in attitudes (Du Toit \& Lachmann 1997:47). However, the situation in most rural schools is such that teachers try to do demonstrations with only one small-scale physics set or a chemistry kit. But, because most of the classes are overcrowded, learners do not benefit from such initiatives. Whatever method is used, physical science practical work requires a combination of demonstrations, selected experiments and hands-on activities for most of the other experiments.

Most rural schools do not have equipment; they claim to do what is termed "theoretical practical". This type of practical work is done theoretically in the classroom. This means that the teacher explains a concept which should have been explained by letting learners participate in a practical activity. The theory on which the practical work is based is provided by the teacher and presented to the learners on the assumption that they will understand the concepts. For example, a teacher was observed trying to explain the operation of a ticker timer in Physics. In his lesson, the teacher said: "Imagine you have a ticker timer and it makes dots on the tape". The teacher then drew a ticker timer and a tape with ticks on the board. Then the teacher copied the results of a previously recorded practical activity. Learners were subsequently expected to interpret the results and apply what they had learnt in relation to problems or questions on the ticker timer.

In contrast, in schools that do have equipment, the learners do the practical activity and come up with results. Learners with equipment can experiment with the ticker timer and come up with dots on the tape for interpretation. Notwithstanding learners' understanding, in both of the abovementioned cases, assessment of practical work includes understanding both the concepts and the practical skills gained. These practical skills include observation, recording, interpretation and handling of equipment. The question is what type of practical skills can learners gain from practical work presented theoretically? Applying Kolb's experiential learning framework becomes a challenge in this case. The argument is, everything about theoretically presented practical work is imagined. There is nothing concrete that the learners can engage with. The learners have to imagine a ticker timer, which they may never have touched or seen. Some of them know how it looks from the picture or drawing in the textbook. Learners have to visualise the ticker timer and imagine it making dots on the tape. The teacher tries to concretise the situation by drawing the ticker timer and the tape with ticks on the board. Learners are being asked to give their observations and reflections on the imagined situation and the drawing. This creates many challenges because people think differently and so they interpret a situation differently. Their views on the concept of a ticker timer are justified within a particular context by means of the rules of inquiry for that context and by context-specific interpretations of the evidence. Learners are expected to make abstractions from previously recorded results of a practical. Knowledge cannot be understood as an abstraction, especially if it is not assumed as absolute and concrete. Certainly, direct observation is crucial in practical work. Knowledge always involves an element of ambiguity because of situational variables, such as incorrect data; hence, practical evidence is necessary so as to make informed abstractions. Acquiring knowledge is a product of a process of reasonable inquiry in which solutions to problems are constructed according to current evidence. This paper argues that without evidence of practical work, correct conclusions and interpretations cannot be made. Conclusions can be defended by presenting the most complete, plausible and compelling understanding of an issue on the basis of the available evidence.

The world has changed economically that the situation regarding schools without equipments as explained in this article should be discouraged. The success of any economy depends on the practical skills and ultimate implementation of these skills to advance the economy of the country. Every country aspires to invest in their own children, hence avoid to be outsourcing skills from other countries. The digital divide that exist in this current economy requires that learners should be well trained in practical related skills. For instance, learners should not find themselves in a situation where they "imagine" and subsequently visualise a science equipment and its operation. If learners are afforded the opportunity to acquire practical skills. They should be in the position to come up with technological innovations that can help develop their respective disadvantaged rural areas, especially the schools.

This article argue that the "imagined" theoretical practical work is an impossible arrangement in the world that is currently governed by a continued development of innovative tools like the smart boards and ICT equipments. The learner in the rural area is not any different from any other learner in the world, he or she should equally contribute to the advancement of the socio-economic status of his or her country.

Obviously, the impact of practical work on performance and its relation to mastering the theory continue to be part of the debates in science education. Many researchers believe that for learners to understand and master the theory, 
practical work should be done. The reality is that many schools do not have equipment to do practical work properly. The chances that learners will succeed in science in schools where there isn't equipment are questionable when taking into consideration the relationship between practical work, theory, practical skills and their ultimate performance. The assessment done at the end of the year does not make any distinction between learners who have done practical work fully, partially or no practical work at all. The assumption is that all learners should perform equally well. The implication is that in an event that these learners succeed with their grade 12, their ability to succeed beyond the first year at university will be a challenge. University courses like engineering require that learners should have the basics in science practical work. Engineering on its own is a practical course and starting to do practical work at the university level will be a challenge for a learner who has never done practical work. Globally, very sophisticated equipments are being developed and it remains to be seen how learners without basic practical skills will compete in the global world. Despite South Africa's economic status, South Africa like many other developing countries need to adopt a practical oriented approach in order to be on par with other countries. This means that, initiatives should be in place to equip all schools with the necessary science equipments irrespective of the location of the school. The long term aim should be to develop learners who will contribute sufficiently to economy of the country.

Notably, we are living in an era of dramatic new technology resources. In addition, globally new standards in science education has been developed in which learning by inquiry has been given renewed central status (Hofstein \& Lunetta 2003). Furthermore, the methodologies for research and assessment have dramatically changed. These include, how science laboratory resources are used, how learner's work in the laboratory is assessed, and how science practical activities can be used by teachers to enhance intended learning outcomes. Whilst other learners do not have basic equipments, technology is already replacing the current science classrooms with computer-based resources such as virtual labs (Scheckler 2003).

For this reason I shall argue that all school science learners (whether in developed or underdeveloped countries) should be part of this exciting developments.

\section{Conclusion}

The aim of this study was to give a reflective picture of practical work as it is currently undertaken in rural science classes in South Africa. What has emerged is that conditions in secondary schools are not satisfactory for doing practical work. Schools that have been provided with equipment do not make use of it. Some expensive apparatus and equipment, which have never been used, were found deteriorating in storerooms and boxes in many of the schools visited. At schools where there is equipment, teachers claim that the school system does not allow enough time to do practical work. This is because teachers spend a lot of time doing administrative work and spend little or no time on practical work. Many of the teachers prefer to do demonstrations, which are very teacher-centred. The focus of many schools is on finishing the syllabi rather than on effective teaching and learning. Many learners do practical work for the first time at university level without having had the proper training and background on how to do such work.

It is imperative that every learner in primary and secondary school do practical work in science. These practical activities should be managed by the learners, while the teacher acts as a facilitator. Such a view is in accordance with theories of motivation, as confirmed by Wigfield (1994), who recommends ceding a greater degree of control of learning to the learner himself/herself. The constructivist theory, in Ausubel (1968), emphasises that learners should construct their own knowledge. To a large extent, practical work does play a role in the learning and teaching of science. Hence, the environment in which learners operate should be devised in such a way that it allows for the construction of knowledge by learners. This article offers insight into the situation of learners in the rural areas of South Africa. It is hoped that this article will contribute to the continuing debates about the lack of resources at schools and it is envisaged that this will, in turn, trigger efforts to find solutions.

If we are to provide sufficient numbers of learners in the field of technology and other science-related professions, the efficient teaching of science at school level should be of the utmost importance. This means that much effort is needed to introduce a more practical approach in science teaching. Teachers should not just opt for lecturing as a major teaching method where there is no equipment, but should endeavour to experiment with creative methods of presentation to find solutions to the challenges. The economy globally has advanced such that, it does not allow for anyone to imagine a science practical instead of doing it hands on. Given the benefits that practical work has in the teaching and learning of science, the arguments in this article calls for a creation of a hands-on environment for all science learners in classrooms across South Africa, in particular the "voiceless" rural disadvantaged schools. 


\section{References}

Abrahams, A. (2009). Does practical work really motivate? A study of the affective value of practical work in secondary school science. International Journal of Science Education. 31(17):2335-2353.

Allsop, T. (1991). Practical science in low-income countries. In BE Woolnough (ed). Practical science: the role and reality of practical work. Milton Keynes: Open University Press, pp 31-40.

Ausubel, D.P. (1968). Educational psychology: a cognitive view. New York: Holt, Rinehart and Winston.

Bentley, D., \& Watts, M. (1989). Learning and teaching in school science. Practical alternatives. Milton Keynes: Open University Press.

Bradley, J.D., Durbach, S., Bell B. \& Mungarulire J 1998. Hands-on practical chemistry for all: why and how. Journal of Chemical Education. 75(11):1406-1409.

Bradley., J. \& Maake., P. (1998). Research report on practical work in colleges of education. Pretoria: National Research Foundation.

Chin, C. (2003). Success with investigations. The Science Teacher. 1:34-40.

Cilliers, J.A., Basson, I., Kirschner, P.A. \& Rutherford, M. (2000). Current views of the purpose of introductory physics laboratory in South Africa. Part 11: specific objectives. South African.Journal of Higher Education. 14(1):20-30.

Coleman, L.A., Holcomb, D.F., \& Rigden, J.S. (1997). The introductory university physics project 1987-1995: what has it accomplished? American Journal of Physics. 66(2):124-137.

Driver, R. (1989). Students' conceptions and the learning of science. International Journal of Science Education. 11(special issue):481490.

Eglen, J.R., \& Kempa, R.E. (1974). Assessing manipulative skills in practical chemistry. School Science Review. 56:261-273.

Gunstone, R.F (1991). Reconstructing theory from practical experience. In BE Woolnough (ed). Practical science: the role and reality of practical work. Milton Keynes: Open University Press, pp 67-77.

Gyllenpalm, J., Wickman, P.O., \& Holmgren, S.O. (2010). Teachers' language on scientific inquiry: methods of teaching or methods of inquiry? International Journal of Science Education. 32(9):1151-1172.

Haslam, C.Y., \& Hamilton, R.J. (2010). Investigating the use of integrated instructions to reduce the cognitive load associated with doing practical work in secondary school science. International Journal of Science Education. 32(13):1715-1737.

Hodson, D. (1992). Redefining and re-orientating practical work in school science. School Science Review. 73(264):65-78.

Hodson, D. (1998). Teaching and learning science, towards a personalised approach. Buckingham: Open University Press.

Hofstein, A., \& Cohen, I. (1996). The learning environment of high school students in chemistry and biology laboratories. Research in Science \& Technological Education. 14(1):103.

Hofstein., A. \& Lunetta, V. (2003). The laboratory in science education: Foundations for the twenty first century. Science Education. 88 : 28-54.

Hofstein, A., \& Lunetta., V. (1991). Simulations and laboratory practical activity. In BE Woolnough (ed). Practical science: the role and reality of practical work. Milton Keynes: Open University Press, pp 125-137.

Kempa., R.F. (1988). Functions of and approaches to practical work in science. In GD Thijs, HH Boer, IG Macfarlane \& CJ Stoll (eds). Learning difficulties and teaching strategies in secondary school science and mathematics. Amsterdam: Vrije Universiteit, pp 147-163.

King, P.M., \& Kitchener, K.S. (2004). Reflective judgment: theory and research on the development of epistemic assumptions through adulthood. Educational Psychologist. 39(1):5-18.

Knowles, M Holton, E.F., \& Swanson, R.A. (2005). The adult learner: the definitive classic in adult education and human resource development. San Diego: Elsevier.

Koballa, T.R. (1992). Persuasion and attitude change in science education. Journal of Research in Science Teaching. 29(1):63-80.

Koballa, T.R., \& Crawley, F.E. (1985). The influence of attitude on science teaching and learning. School Science and Mathematics. 85(3):223-231.

Lunetta, V.N., Hofstein, A \& Clough, M.P. (2007). Teaching and learning in the school science laboratory. An analysis of research, theory, and practice. In S K Abell \& NG Lederman (Eds). Handbook of Research on Science Education. Mahwah, NJ: Lawrence Erlbaum Associates, pp. 393-431.

McMahon, T. (1999). Is reflective practice synonymous with action research? Educational Action Research. 7(1).

Merriam, S.B. (1998). Qualitative research and case study applications in education. Revised and expanded from case study research in education. San Francisco: Jossey-Bass.

Millar, R. (2004). The role of practical work in the teaching and learning of science. Paper prepared for the committee: High school science laboratories: Role and vision, National Academy of Sciences, Washington DC. York: University of York.

Millar, R. (1991). A means to an end: the role of processes in science education. In BE Woolnough (ed). Practical science: the role and reality of practical work. Milton Keynes: Open University Press, pp 43-52.

Millar, R., Tiberghien, A., \& Le Marechal, J-F. (2002). Varieties of labwork: a way of profiling labwork tasks. In D Psillos \& H Niedderer (eds). Teaching and learning science in the laboratory. Dordrecht: Kluwer, pp 9-20.

Nicholls, D. (2009a). Qualitative research: part one - philosophies. International Journal of Therapy and Rehabilitation. 16(10):526-533.

Nicholls, D. (2009b). Qualitative research: part three - methods. International Journal of Therapy and Rehabilitation. 16(12):638-647.

Scheckler, R.K. (2003). Virtual labs: a substitute for traditional labs. International journal of developmental biology. 47:231-236

Tamir, P. (1991). Practical work in school science: an analysis of current practice. In BE Woolnough (ed). Practical science: the role and reality of practical work. Milton Keynes: Open University Press, pp 13-20. 
TIMMS, (2011). The Third International Mathematics and Science Study. Slough: NFER

Treagust, D.F., \& Thair, M. (1999). Teacher training reforms in Indonesian secondary science: the importance of practical work in physics. Journal of Research in Science Teaching. 36(3):357-371.

Trumper, R. (2003). The physics laboratory - a historical overview and future perspectives. Science and Education. 12(7):645-670.

Van der Linde, H.J., Van der Wal., R.W.E., \& Wilkinson, A. (1994). Practical work in science teaching in developing communities. South African Journal of Education 14(1):48-52.

Van Rensburg, J.J., \& Potloane., V. (1998). Outcomes-based teaching and learning: concepts and essentials, in F Pretorius (ed). Outcomes based education in South Africa. South Africa: Hodder \& Stoughton.

Van Rensburg, L.D., \& Bitzer, E.M (1995). Enhancement of learning in basic chemistry. South African Journal of Higher Education. 9(1):137-141.

White, R.T., \& Gunstone, R.F. (1992). Probing Understanding. London: Falmer Press.

Wigfield, A. (1994). Expectancy-value theory of achievement motivation: a developmental perspective. Educational Psychology Review. 6:49-78.

Woolnough, B. (1991). Practical science. Milton Keynes: Open University Press.

Yager, R.E. (1991). The centrality of practical work in science/technology/society movement. In BE Woolnough (ed). Practical science: the role and reality of practical work. Milton Keynes: Open University Press, pp 21-30. 
